\title{
Kinetics of the Reactions of Formaldehyde with Substituted Benzamides in Water
}

\author{
IRMA TARVAINEN and JOUKO KOSKIKALLIO* \\ Department of Chemistry, University of Oulu, Oulu, Finland
}

\begin{abstract}
Rate constants of the reactions of formaldehyde with parasubstituted benzamides in water were measured over a wide $\mathrm{pH}$ range. The rate constants of the reactions of formaldehyde with the benzamide anion and the base constants of the methylene glycol anion, substituted benzamide anions, and substituted methylolbenzamide anions were evaluated from data for the reactions in alkaline solutions at $0^{\circ} \mathrm{C}$. Both general acid and general base catalysis were observed in acetate buffer solutions, but only a salt effect in phosphate buffer solutions. Uncatalysed hydrolysis is interpreted as a general acid catalysis by water.
\end{abstract} Tormaldehyde is known to react with amides to give methylolamides. ${ }^{1-2}$
The reactions are reversible:

$$
\mathrm{RCONH}_{2}+\mathrm{CH}_{2} \mathrm{O} \underset{k_{-1}}{\stackrel{k_{2}}{\rightleftharpoons}} \mathrm{RCONHCH}_{2} \mathrm{OH}
$$

Both general acid and general base catalysis have been observed and several mechanisms have been proposed for these reactions. ${ }^{3-7}$ In order to obtain more information on these reactions, the rates of the reactions of formaldehyde with substituted benzamides have been measured in water solutions covering a wide $\mathrm{pH}$ range.

\section{EXPERIMENTAL}

Materials. The acid amides were recrystallized from water and acetone. The melting points were $128^{\circ} \mathrm{C}$ for benzamide (Fluka AG, purum), $164^{\circ} \mathrm{C}$ for $p$-methoxybenzamide (EGA) and $201^{\circ} \mathrm{C}$ for $p$-nitrobenzamide prepared from $p$-nitrobenzoyl chloride (Fluka AG, purum). A carbonate-free stock solution of sodium hydroxide (1 part) in water (1 part) was diluted for use in the kinetic experiments. Aqueous formaldehyde solutions were prepared by dissolving paraformaldehyde (E. Merck AG, purum) in boiling water. Acetic acid, sodium acetate, sodium dihydrogen phosphate, disodium hydrogen phosphate,

* Present address: Department of Chemistry, University of Helsinki, Helsinki, Finland.

Acta Chem. Scand. 24 (1970) No. 4 
sodium chloride, and hydrochloric acid, all guaranteed reagents from E. Merck AG., were used as received.

Kinetic experiments. Each sample was analysed for formaldehyde content either by the cyanide method ${ }^{8}$ or by the bisulphite method ${ }^{4}$ after cooling it and adjusting its $\mathrm{pH}$ to arrest the reaction and to obtain optimum conditions for analysis. The rate of the fast reactions in aqueous sodium hydroxide solution at $0^{\circ} \mathrm{C}$ were measured in twocomponent reaction vessels.' All the other reactions were run in vapour-free $4 \mathrm{ml}$ ampoules in which the capillary was sealed with a mercury droplet. Stable end points were obtained in the alkaline solutions and the simultaneous Cannizzaro reaction of formaldehyde and alkaline hydrolysis of benzamide did not interfere. In acid solutions in which the hydro. chloric acid concentration exceeded $0.02 \mathrm{M}$, the formaldehyde content slowly increased and a white solid indicating a consecutive reaction to bismethylenebenzamide precipitated. The rate law for two opposing reactions

gives, when integrated,

$$
\mathrm{d} x / \mathrm{d} t=k_{2}(a-x)(b-x)-k_{1} x
$$

$$
k_{\mathrm{a}} t=x_{\mathrm{e}} /\left(a^{2}-x_{\mathrm{e}}^{2}\right)\left[\ln x_{\mathrm{e}}\left(a^{2}-x x_{\mathrm{e}}\right) / a^{2}\left(x_{\mathrm{e}}-x\right)\right]
$$

where $a$ and $b$ are the initial concentrations of formaldehyde and benzamide, respectively, and $x_{\mathrm{e}}$ the concentration of the formed methylolbenzamide at equilibrium. Values of the rate constant $k_{2}$ calculated from eqn. (3) were constant over wide ranges of the reactions.

\section{RESULTS AND DISCUSSION}

The reaction between formaldehyde and benzamide is catalysed by hydrochloric acid. As expected, the rate was proportional to the hydrochloric acid concentration in the range from $0.001 \mathrm{M}$ to $0.02 \mathrm{M}$. Benzamide ${ }^{10}\left(\mathrm{p} K_{\mathrm{a}}=\right.$ 2.1 at $20^{\circ} \mathrm{C}$ ) is protonated to a negligible extent (less than $0.02 \%$ ) in the solutions used in the kinetic experiments. The evaluated second-order rate constants are given in Table 1 . The value $k_{\mathrm{H}}=9.0 \times 10^{-3} \mathrm{M}^{-2} \mathrm{sec}^{-1}$ at $70^{\circ} \mathrm{C}$

Table 1. Rate constants of the hydrochloric acid-catalysed reversible reaction between formaldehyde and acetamide in water. Mean values of rate constants for the opposing reaction in solutions 0.001 to $0.02 \mathrm{M}$ in hydrogen chloride.

\begin{tabular}{llll}
$t^{\circ} \mathrm{C}$ & $\begin{array}{c}10^{3} k_{2} \\
\mathrm{M}^{-2} \mathrm{sec}^{-2}\end{array}$ & $\begin{array}{c}10^{3} k_{-1} \\
\sec ^{-1}\end{array}$ & $\begin{array}{c}K_{\mathrm{e}} \\
\mathrm{M}^{-1}\end{array}$ \\
\hline 60 & 3.97 & 0.423 & 9.38 \\
75 & 15.5 & 1.82 & 7.43 \\
90 & 47.6 & 8.9 & 5.35
\end{tabular}

reported by Uglestad and de Jonge ${ }^{5}$ is close to the value of $8.8 \times 10^{-3} \mathrm{M}^{-2} \mathrm{sec}^{-1}$ calculated from the values in Table 1 . The mechanism of the acid-catalysed reaction is discussed later together with the general acid catalysis observed in buffer solutions.

Reactions of formaldehyde with para-substituted benzamides in aqueous sodium hydroxide solution. In addition to the slow reaction (4), several fast equilibria including proton exchange reactions and hydratation of formaldehyde are involved in the reactions of formaldehyde with amides in alkaline solutions: 


$$
\begin{array}{ll}
\mathrm{RCONH}^{-}+\mathrm{CH}_{2} \mathrm{O} \underset{k_{-1}}{\stackrel{k_{2}}{\rightleftharpoons}} \mathrm{RCONHCH}_{2} \mathrm{O}^{-} & \\
\mathrm{RCONH}^{-}+\mathrm{H}_{2} \mathrm{O}=\mathrm{RCONH}_{2}+\mathrm{OH}^{-} & K_{\mathrm{a}}=\frac{\left[\mathrm{RCONH}_{2}\right]\left[\mathrm{OH}^{-}\right]}{\left[\mathrm{RCONH}^{-}\right]} \\
\mathrm{RCOHCH}_{2} \mathrm{O}^{-}+\mathrm{H}_{2} \mathrm{O}=\mathrm{RCONHCH}_{2} \mathrm{OH}+\mathrm{OH}^{-} & K_{\mathrm{m}}=\frac{\left[\mathrm{RCONHCH}_{2} \mathrm{OH}\right]\left[\mathrm{OH}^{-}\right]}{\left[\mathrm{RCONHCH} \mathrm{O}^{-}\right]} \\
\mathrm{CH}_{2}(\mathrm{OH}) \mathrm{O}^{-}+\mathrm{H}_{2} \mathrm{O}=\mathrm{CH}_{2}(\mathrm{OH})_{2}+\mathrm{OH}^{-} & K_{\mathrm{f}}=\frac{\left[\mathrm{CH}_{2}(\mathrm{OH})_{2}\right]\left[\mathrm{OH}^{-}\right]}{\left[\mathrm{CH}_{2}(\mathrm{OH}) \mathrm{O}^{-}\right]} \\
\mathrm{CH}_{2} \mathrm{O}+\mathrm{H}_{2} \mathrm{O}=\mathrm{CH}_{2}(\mathrm{OH})_{2} & K=\frac{\left[\mathrm{CH}_{2}(\mathrm{OH})_{2}\right]}{\left[\mathrm{CH}_{2} \mathrm{O}\right]}
\end{array}
$$

The total concentrations of aldehyde $c_{\mathrm{f}}$, amide $c_{\mathrm{a}}$, and methylolamide $c_{\mathrm{m}}$ are

$$
\begin{gathered}
c_{\mathrm{f}}=\left[\mathrm{CH}_{2} \mathrm{O}\right]+\left[\mathrm{CH}_{2}(\mathrm{OH})_{2}\right]+\left[\mathrm{CH}_{2}(\mathrm{OH}) \mathrm{O}^{-}\right] \\
c_{\mathrm{a}}=\left[\mathrm{RCONH}_{2}\right]+\left[\mathrm{RCONH}^{-}\right] \\
c_{\mathrm{m}}=\left[\mathrm{RCOHCH}_{2} \mathrm{OH}\right]+\left[\mathrm{RCONHCH}_{2} \mathrm{O}^{-}\right]
\end{gathered}
$$

When the concentrations $\left[\mathrm{CH}_{2}(\mathrm{OH})_{2}\right],\left[\mathrm{CH}_{2}(\mathrm{OH}) \mathrm{O}^{-}\right],\left[\mathrm{RCONH}_{2}\right]$, and $\left[\mathrm{RCONHCH}_{2} \mathrm{OH}\right]$ obtained from eqns. (5) $-(8)$, respectively, are substituted in eqns. $(9)-(11)$, the concentrations $\left[\mathrm{CH}_{2} \mathrm{O}\right],\left[\mathrm{RCONH}{ }^{-}\right]$, and $\left[\mathrm{RCONHCH}_{2} \mathrm{O}^{-}\right]$ can be expressed in terms of the total concentrations $c_{\mathrm{f}}, c_{\mathrm{a}}, c_{\mathrm{m}}$, and $\left[\mathrm{OH}^{-}\right]$ and the equilibrium constants of reactions (5) $-(8)$.

The rate of the reaction is:

$$
\begin{gathered}
\text { Rate }=k_{2}\left[\mathrm{RCONH}^{-}\right]\left[\mathrm{CH}_{2} \mathrm{O}\right]-k_{-1}\left[\mathrm{RCONHCH}_{2} \mathrm{O}^{-}\right] \\
=k_{2} \frac{1}{K_{\mathrm{a}} /\left[\mathrm{OH}^{-}\right]+1} \frac{1}{K\left[\mathrm{OH}^{-}\right] / K_{\mathrm{f}}+K+1} c_{\mathrm{a}} c_{\mathrm{f}}-k_{-1} \frac{1}{K_{\mathrm{m}} /\left[\mathrm{OH}^{-}\right]+1} c_{\mathrm{m}} \\
=k_{2}{ }^{\prime} c_{\mathrm{a}} c_{\mathrm{f}}-k_{-1}{ }^{\prime} c_{\mathrm{m}}
\end{gathered}
$$

As the base constants of methylene glycol, acetamide, and methylolacetamide anions are relatively high in value, the equilibrium concentration of hydroxide ion is close to its total concentration. From eqns. (13) and (14), the following expressions are obtained for the rate constants $k_{2}{ }^{\prime}$ and $k_{-1}{ }^{\prime}$ :

$$
\begin{gathered}
1 / k_{2}{ }^{\prime}=\left(K / k_{2}\right)\left(1+K_{\mathrm{a}} /\left[\mathrm{OH}^{-}\right]\right)\left(1+\left[\mathrm{OH}^{-}\right] / K_{\mathrm{f}}\right) \\
1 / k_{-1}^{\prime}=1 / k_{-1}\left(1+K_{\mathrm{m}} /\left[\mathrm{OH}^{-}\right]\right)
\end{gathered}
$$

when $K \gg 1$. By fitting eqns. (15) and (16) to the experimental rate constants $k_{2}{ }^{\prime}$ and $k_{-1}$, values were obtained for the rate constants $k_{2}$ and $k_{-1}$ as well as for the equilibrium constants $K_{\mathrm{a}}, K_{\mathrm{f}}$, and $K_{\mathrm{m}}$. When $k_{2}$ was calculated, the value $K=8.2 \times 10^{3}$ at $0^{\circ} \mathrm{C}$ derived from the values $K=2.22 \times 10^{3}$ at $25^{\circ} \mathrm{C}$ and $\Delta H=-8.0 \mathrm{kcal} / \mathrm{mole}$ reported by Bell was employed. ${ }^{11,12}$ The results are shown in Tables 2 and 3.

The value of $K_{\mathrm{f}}$ has been reported previously to be $0.114 \mathrm{M}$ at $0^{\circ} \mathrm{C}^{13}$ From values obtained at other temperatures, ${ }^{13,14}$ a value of about $0.091 \mathrm{M}$ was calculated. The mean value $K_{\mathrm{f}}=0.086 \mathrm{M}$ obtained in the present work is in agreement with these results. The value $K_{\mathrm{m}}=0.125 \mathrm{M}$ reported ${ }^{5}$ for methyl- 
Table 2. Observed and calculated values of the second-order rate constants of reactions of formaldehyde with para-substituted benzamides in aqueous sodium hydroxide solutions at $0^{\circ} \mathrm{C}$. The rate constants were calculated from eqns. (15) and (16) and the values of the constants given in Tables 1 and 3 .

\begin{tabular}{|c|c|c|c|c|c|}
\hline Substituent & $\underset{\mathbf{M}}{\left[\mathrm{OH}^{-}\right]}$ & $\begin{array}{c}\text { Obs. } \\
10^{3} k_{2} \\
\mathrm{M}^{-1} \mathrm{gec}^{-1}\end{array}$ & $\begin{array}{c}\text { Calc. } \\
10^{3} k_{2} \\
\mathrm{M}^{-1} \mathrm{sec}^{-1}\end{array}$ & $\begin{array}{l}\text { Obs. } \\
10^{3} k_{-1} \\
\text { sec }^{-1}\end{array}$ & $\begin{array}{c}\text { Calc. } \\
10^{3} k_{-1} \\
\sec ^{-1}\end{array}$ \\
\hline \multirow[t]{7}{*}{ None } & 0.0101 & 6.25 & 6.65 & 0.113 & 0.114 \\
\hline & 0.0203 & 12.2 & 12.1 & 0.218 & 0.214 \\
\hline & 0.0402 & 20.7 & 19.9 & 0.408 & 0.382 \\
\hline & 0.0795 & 33.0 & 29.6 & 0.680 & 0.625 \\
\hline & 0.161 & 42.2 & 39.0 & 0.928 & 0.938 \\
\hline & 0.281 & 44.6 & 44.2 & 1.04 & 1.18 \\
\hline & 0.618 & 46.9 & 53.6 & 1.20 & 1.46 \\
\hline \multirow{7}{*}{$p \cdot \mathrm{MeO}$} & 0.0100 & 5.03 & 5.05 & 0.095 & 0.095 \\
\hline & 0.0199 & 11.7 & 9.0 & 0.229 & 0.179 \\
\hline & 0.0355 & 14.1 & 13.8 & 0.301 & 0.293 \\
\hline & 0.0796 & 23.2 & 22.2 & 0.548 & 0.534 \\
\hline & 0.159 & 28.8 & 29.3 & 0.713 & 0.797 \\
\hline & 0.177 & 30.6 & 30.4 & 0.769 & 0.840 \\
\hline & 0.272 & 30.3 & 33.6 & 1.12 & 1.01 \\
\hline \multirow[t]{5}{*}{$p-\mathrm{NO}_{2}$} & 0.0173 & 43.5 & 41.5 & 1.09 & 1.09 \\
\hline & 0.341 & 58.9 & 63.3 & 1.66 & 1.85 \\
\hline & 0.0693 & 82.2 & 81.5 & 2.70 & 2.92 \\
\hline & 0.103 & 87.1 & 84.5 & 4.56 & 3.62 \\
\hline & 0.138 & 85.9 & 83.2 & 4.27 & 4.08 \\
\hline
\end{tabular}

Table 3. Equilibrium and rate constants (eqns. (4)-(8)) of reactions of formaldehyde with substituted acetamides $\mathrm{RCONH}$, in water containing sodium hydroxide at $0^{\circ} \mathrm{C}$. The value $K=8.2 \times 10^{3}$ derived for equilibrium (8) from the values $K=2.22 \times 10^{3}$ at $25^{\circ} \mathrm{C}$ and $\Delta H=-8.0 \mathrm{kcal} / \mathrm{mole}$ reported by Bell ${ }^{12}$ was used in the calculations. Mean $K_{\mathrm{f}}=0.083 \pm 0.01$. The value for acetamide was recalculated from previous data."

\begin{tabular}{|c|c|c|c|c|c|c|}
\hline $\mathbf{R}$ & $\begin{array}{l}K_{\mathrm{f}} \\
\mathbf{M}\end{array}$ & $\begin{array}{l}K_{\mathbf{a}} \\
\mathbf{M}^{2}\end{array}$ & $\frac{10^{-8} k_{2}}{\mathrm{M}^{-1} \sec ^{-1}}$ & $\underset{\mathrm{M}}{K_{\mathrm{m}}}$ & $\begin{array}{c}10^{3} k_{-1} \\
\sec ^{-1}\end{array}$ & $\sigma_{\mathbf{p}}^{*}$ \\
\hline $\begin{array}{l}p-\mathrm{NO}_{2} \cdot \mathrm{C}_{6} \mathrm{H}_{4} \\
\mathrm{C}_{6} \mathrm{H}_{5} \\
p-\mathrm{MeOC}_{6} \mathrm{H}_{4} \\
\mathrm{CH}_{3}\end{array}$ & $\begin{array}{l}0.089 \\
0.083 \\
0.076 \\
0.107 \\
\end{array}$ & $\begin{array}{c}0.12 \\
3.6 \\
17.4 \\
4.8 \\
\end{array}$ & $\begin{array}{l}3.28 \\
22.2 \\
82 \\
3.9 \\
\end{array}$ & $\begin{array}{l}0.091 \\
0.151 \\
0.156 \\
0.142\end{array}$ & $\begin{array}{l}6.8 \\
1.82 \\
1.58 \\
26.4 \\
\end{array}$ & $\begin{array}{c}+0.778 \\
0 \\
-0.268\end{array}$ \\
\hline$\varrho^{*}$ & & 1.97 & -1.23 & -0.24 & 0.63 & \\
\hline
\end{tabular}

olbenzamide at $0^{\circ} \mathrm{C}$ differs somewhat from the value $K_{\mathrm{m}}=0.151 \mathrm{M}$ in Table 3. The values of $K_{\mathrm{a}}$ are very approximate owing to experimental errors and because activity coefficients and salt effects have been neglected. Values varying from 1 to $10 \mathrm{M}$ have been reported ${ }^{15}$ for $K_{\mathrm{a}}$ of benzamide at $25^{\circ} \mathrm{C}$ and the value $K_{\mathrm{a}}=12 \mathrm{M}$ has been obtained for acetamide from conductometric measurements. The value obtained for benzamide is $K_{\mathrm{a}}=3.6 \mathrm{M}$ in water at $0^{\circ}$. 
The value $k_{-1}=1.25 \times 10^{2} \mathrm{sec}^{-1}$ at $0^{\circ} \mathrm{C}$ reported previously ${ }^{5}$ is somewhat lower than the value $k_{-1}=1.82 \times 10^{-3} \mathrm{sec}^{-1}$ in Table 3 .

The basicities of both benzamide and methylolbenzamide decrease when an electron-withdrawing $p$-nitro substituent is introduced and the values of the constant $\varrho^{*}$ in the Hammett equation are -1.97 and -0.24 , respectively. The substituent effect is much stronger for benzamide than for methylolbenzamide because the distance between reaction centre and the substituent is larger in methylolbenzamide. Large substituent effects are also revealed by the base constants of the benzamides $\left(\varrho^{*}=-1.97\right)$ when these are compared with the effects of the same substituents on the base constants of benzoates $\left(\varrho^{*}=-1\right.$, by definition).

Substituents have opposite effects on the rate constants $k_{2}$ and $k_{-1}$ of two opposing reactions. An electron-withdrawing $p$-nitro substituent retards the rate of the reaction between formaldehyde and benzamide anion by decreasing the electron density at the nitrogen atom. This substituent effect $\left(\varrho^{*}=-1.23\right)$ can be compared with the substituent effects of the same group on proton abstraction $\left(\varrho^{*}=-1.97\right)$ and the reverse reaction $\left(\varrho^{*}=+0.63\right)$. If the negative charge is assumed to be distributed in the transition state between the nitrogen and oxygen atoms only<smiles>[X]c1ccc(C(=O)N=CC([2H])O[CH])cc1</smiles>

and a fraction $\alpha$ of the negative charge is taken to be on the nitrogen atom and a fraction $1-\alpha$ on the oxygen atom, $\alpha$ can be calculated from the equations:

$$
\begin{gathered}
\alpha(-1.97)-(1-\alpha)(-0.24)=-1.23 \\
-(1-\alpha)(-1.97)+\alpha(-0.24)=+0.63
\end{gathered}
$$

The values 0.665 and 0.605 are obtained for $\alpha$ from eqns. (18) and (19), respectively. The charge is not equally distributed between oxygen and nitrogen atoms in the transition state, which hence resembles the reactant more than the product. The differences in the values of $k_{2}$ and $k_{-1}$ for the reactions of acetamide and benzamide with formaldehyde indicate a steric effect of the large phenyl group.

In a previous work 4 a mechanism was proposed for the reaction between formaldehyde and acetamide in which the reaction between the methylene glycol anion and acetamide was assumed to be the slow step. At low alkali concentrations this mechanism and the mechanism shown in eqn. (4) are kinetically indistinguishable. However, as the amide anion is a stronger nucleophile than the amide itself and as the carbon atom in formaldehyde is a stronger electrophile than the carbon atom in methylene glycol or its anion, the mechanism shown in eqn. (2) is more probable.

General acid and general base catalysis of the reaction between formaldehyde and benzamide in water. The second-order rate constant of reaction in a buffer 
solution may be equal to the sum of several terms due to various simultaneous catalytic reactions:

where

$$
k_{2}=k_{\mathrm{w}}+k_{\mathrm{H}} c_{\mathrm{H}}+k_{\mathrm{OH}} c_{\mathrm{OH}}+k_{\mathrm{HA}} c_{\mathrm{HA}}+k_{\mathrm{A}} c_{\mathrm{A}}=k^{\prime}+\alpha c_{\mathrm{A}}
$$

$$
\begin{aligned}
& k^{\prime}=k_{\mathrm{w}}+k_{\mathrm{H}} c_{\mathrm{H}}+k_{\mathrm{OH}} c_{\mathrm{OH}} \\
& \alpha=r k_{\mathrm{HA}}+k_{\mathrm{A}} ; r=c_{\mathrm{HA}} / c_{\mathrm{A}}
\end{aligned}
$$

In acetic acid - sodium acetate buffer solutions, HA denotes acetic acid and A the acetate ion. When the buffer ratio $r$ is held constant and sodium acetate concentration altered at constant ionic strength, $k^{\prime}$ and $\alpha$ can be evaluated from the linear plot of $k_{2}$ against $c_{\mathrm{A}}$. The values obtained are shown in Table 4. Both $k_{\mathrm{HA}}$ and $k_{\mathrm{A}}$ were evaluated from the linear plot of $\alpha$ against $r$. Their

Table 4. Values of constants $r$ and $\alpha$ of eqn. (22) for the reaction between formaldehyde and benzamide in aqueous acetic acid-sodium acetate buffer solutions of constant

\begin{tabular}{|c|c|c|c|c|c|}
\hline$t^{\circ} \mathrm{C}$ & $r$ & pH & $\begin{array}{c}10^{6} k^{\prime} \\
M^{-1} \mathrm{gec}^{-1}\end{array}$ & $\begin{array}{c}10^{4} \alpha \\
M^{-2} \sec ^{-1}\end{array}$ & $\underset{\mathbf{M}^{-1}}{K_{\mathbf{e}_{1}}}$ \\
\hline \multirow[t]{3}{*}{60} & 0.125 & 5.57 & 0.0519 & 0.110 & 11.33 \\
\hline & 0.937 & 4.70 & 0.0168 & 0.374 & 11.8 \\
\hline & 1.25 & 4.57 & 0.0142 & 0.491 & 11.5 \\
\hline \multirow[t]{3}{*}{75} & 0.125 & 5.62 & 0.335 & 0.410 & 6.89 \\
\hline & 0.938 & 4.74 & 0.087 & 1.35 & 6.77 \\
\hline & 1.25 & 4.62 & 0.073 & 1.84 & 6.79 \\
\hline \multirow[t]{7}{*}{90} & 0.125 & 5.68 & 1.95 & 1.04 & 5.37 \\
\hline & 0.313 & 5.18 & 0.93 & 1.55 & 5.52 \\
\hline & 0.625 & 4.98 & 0.46 & 4.04 & 6.37 \\
\hline & 0.939 & 4.80 & $\mathbf{0 . 3 4}$ & 4.15 & 5.40 \\
\hline & 1.25 & 4.68 & 0.245 & 5.21 & 5.43 \\
\hline & 1.88 & 4.50 & 0.160 & 7.51 & 5.31 \\
\hline & 5.64 & 4.02 & 0.125 & 18.5 & 5.38 \\
\hline
\end{tabular}
ionic strength $(I=0.197)$. The concentration of sodium acetate was varied from $0.01 \mathrm{M}$ to $0.197 \mathrm{M}$ and sodium chloride was added to obtain the constant ionic strength.

Table 5. Rate and equilibrium constants of the uncatalysed reaction $\left(k_{\mathrm{w}}\right)$ and the hydroxide ion $\left(k_{\mathrm{OH}}\right)$, acetic acid $\left(k_{\mathrm{HA}}\right)$ and acetate ion catalysed $\left(k_{\mathrm{B}}\right)$ reactions of formaldehyde with benzamide calculated from measured rate constants in aqueous acetate buffer solutions. The values of $k_{\mathrm{H}}$ are from Table 1 .

\begin{tabular}{ccccccc}
\hline$t^{\circ} \mathrm{C}$ & $\begin{array}{c}10^{4} k_{\mathrm{w}} \\
\mathrm{M}^{-1} \mathrm{sec}^{-1}\end{array}$ & $\begin{array}{c}10^{4} k_{\mathrm{H}} \\
\mathrm{M}^{-2} \mathrm{sec}^{-2}\end{array}$ & $\begin{array}{c}k_{\mathrm{OH}} \\
\mathrm{M}^{-2} \mathrm{sec}^{-2}\end{array}$ & $\begin{array}{c}10^{4} k_{\mathrm{HA}} \\
\mathrm{M}^{-2} \mathrm{sec}^{-2}\end{array}$ & $\begin{array}{c}10^{4} k_{\mathrm{A}} \\
\mathrm{M}^{-2} \mathrm{sec}^{-2}\end{array}$ & $\begin{array}{c}K_{\mathrm{c}} \\
\mathrm{M}^{-1}\end{array}$ \\
\hline 90 & 0.010 & 39.7 & 80 & 0.333 & 0.067 & 11.5 \\
90 & 0.040 & 135 & 240 & 1.24 & 0.24 & 6.82 \\
& $(0.020)$ & 476 & 840 & 3.66 & 0.50 & 5.40
\end{tabular}


values are shown in Table 5 . When values of $k_{2}-k_{\mathrm{H}} \cdot c_{\mathrm{H}}$ were plotted against $c_{\mathrm{OH}}$, the values of $k_{\mathrm{w}}$ and $k_{\mathrm{OH}}$ shown in Table 5 were obtained. The values of $k_{\mathrm{H}}$ were taken from Table 1. Values of $c_{\mathrm{H}}$ and $c_{\mathrm{OH}}$ were calculated using values of the acid constant of acetic acid ${ }^{16}$ and the ionic product of water ${ }^{17}$ and values of activity coefficients calculated from the Debye-Hückel equation ${ }^{16}$ taking the value of a to be $4 \times 10^{-8} \mathrm{~cm}$. A slight error is introduced in the calculations because the extended Debye-Hückel equation does not apply very well at the ionic strengths used in the experiments.

The values $k_{\mathrm{HA}}=8.1 \times 10^{-5} \mathrm{M}^{-2} \mathrm{sec}^{-1}$ for the reaction catalysed by acetic acid and $k_{\mathrm{w}}=2.5 \times 10^{-6} \mathrm{sec}^{-1}$ for the uncatalysed reaction in water at $70^{\circ} \mathrm{C}$ reported by Uglestad and de Jonge ${ }^{5}$ are close to the values $k_{\mathrm{HA}}=8.1 \times 10^{-5}$ $\mathrm{M}^{-2} \mathrm{sec}^{-1}$ and $k_{\mathrm{w}}=2.5 \times 10^{-6} \mathrm{sec}^{-1}$ calculated from the values in Table 5 . No catalysis by acetate ion has been previously observed. ${ }^{5}$ The weak acetate ion catalysis could be observed in this work presumably because buffer solutions of constant ionic strength were used.

When the calculated values of the second-order rate constant of the reaction between formaldehyde and benzamide in sodium dihydrogen phosphate disodium hydrogen phosphate buffer solutions at constant ionic strength were substituted in eqn. (20) derived for the same reaction in acetic acid sodium acetate buffer solutions, values of $\alpha$ were obtained which could not be interpreted in the usual way (eqn. (22)). Instead, it was found that

$$
\alpha=b k^{\prime}
$$

which shows that the terms involving $k_{\mathrm{HA}}$ and $k_{\mathrm{A}}$ in eqn. (20) are negligible. Also the terms involving $k_{\mathrm{w}}$ and $k_{\mathrm{H}}$ were found to be negligible in the $\mathrm{pH}$ range of the phosphate buffer solutions. It follows that

and

$$
k^{\prime}=k_{\mathrm{OH}} c_{\mathrm{OH}}
$$

$$
k_{2}=k_{\mathrm{OH}} c_{\mathrm{OH}}+b k_{\mathrm{OH}} c_{\mathrm{OH}} c_{\mathrm{A}}
$$

The second term in eqn. (25) results from a special salt effect of sodium dihydrogen phosphate, disodium hydrogen phosphate, and sodium chloride at constant ionic strength on the hydroxide ion catalysed reaction. The small variation of the constant $b$ with temperature (Table 6) is also in agreement

Table 6. Rate and equilibrium constants of the hydroxide ion-catalysed reaction between formaldehyde and benzamide in sodium dihydrogen phosphate-disodium hydrogen phosphate buffer solutions at constant ionic strength $I=0.271$ and values of the constant $b$ of the linear salt effect eqn. (23). The concentration of $\mathrm{Na}_{2} \mathrm{HPO}$, varied from $0.005 \mathrm{M}$ to $0.06 \mathrm{M}$, and the ratios of the concentrations of $\mathrm{Na}_{2} \mathrm{HPO}$, and $\mathrm{NaH}_{2} \mathrm{PO}_{4}$ were 0.5 , 1.67, and 4.77.

\begin{tabular}{lcccc}
$t^{\circ} \mathrm{C}$ & $40^{\circ}$ & $60^{\circ}$ & $75^{\circ}$ & $90^{\circ}$ \\
$k_{\mathrm{OH}}, \mathrm{M}^{-2} \mathrm{sec}^{-2}$ & \multicolumn{1}{c}{30} & 100 & 240 & 510 \\
$b, \mathrm{M}^{-1}$ & 5.4 & 5.7 & 5.7 & 6.0 \\
$K_{\mathrm{e}}, \mathrm{M}^{-1}$ & 15.5 & 10.0 & 7.2 & 5.45
\end{tabular}

Acta Chem. Scand. 24 (1970) No. 4 
with this assumed salt effect. Because of the strong hydroxide ion catalysis in phosphate buffer solutions, the weak acid catalysis by dihydrogen phosphate ion cannot be detected.

A linear Brønsted plot of the values of $\log k$ for the reactions of formaldehyde with benzamide catalysed by hydrogen ion, acetic acid, and water against the $\log K_{\mathrm{a}}$ values of the catalyst acids has a slope of 0.31 . The linearity of the plot indicates that also the uncatalysed reaction is an acid catalysis by water. More data would, however, be desirable, to confirm this interpretation.

The mechanism of the general acid catalysed reaction between formaldehyde and benzamide involves either a slow proton transfer from the catalyst acid to formaldehyde or a fast proton transfer and a consecutive slow abstraction of a proton from the benzamide by a base. These two mechanisms are kinetically indistinguishable.

$$
\mathrm{HA}+\mathrm{CH}_{2} \mathrm{O}+\left.\mathrm{NH}_{2} \mathrm{COR} \rightleftharpoons \mathrm{A} \cdots \mathrm{H} \cdots \mathrm{O} \cdots\right|_{\mathrm{H}} ^{\mathrm{C}} \cdots \mathrm{NH}_{2} \mathrm{COR} \rightarrow \text { products }
$$

Evidence supporting the mechanism (26) involving a slow proton transfer to formaldehyde has been obtained ${ }^{18}$ for reactions between formaldehyde and amines. The low value 0.30 of the Brønsted slope indicates that proton transfer has occurred to the extent of only about 0.30 in the transition state. In the hydroxide ion catalysed reaction the extent of proton transfer in the transition state is about 0.37 .

Two indistinguishable mechanisms are possible also for the general base catalysed reaction, one which involves a fast abstraction of a proton from benzamide by the base followed by nucleophilic attack and a slow proton transfer to the aldehyde and one which involves a slow abstraction of a proton from benzamide by a base ${ }^{18}$ simultaneously with the nucleophilic attack:

$$
\mathrm{B}+\mathrm{NH}_{2} \mathrm{COR}+\mathrm{CH}_{2} \mathrm{O} \rightleftharpoons \mathrm{B} \cdots \mathrm{H} \cdots \mathrm{N}_{\mathrm{RCO}}^{\mathrm{H}} \cdots \mathrm{C}_{\mathrm{H}}^{\mathrm{H}} \cdots \mathrm{O} \rightarrow \text { products }
$$

Using the values of equilibrium constants reported ${ }^{12}$ for the hydratation equilibrium of formaldehyde, activation parameters for the reaction between unhydrated formaldehyde and benzamide were calculated. These are shown in Table 6. Enthalpy and entropy changes of the reaction calculated from the values of equilibrium constants are shown in Table 7. The value $\Delta H=-5.0$ kcal mole ${ }^{-1}$ reported by Uglestad and de Jonge ${ }^{5}$ is close to the value, $\Delta H=$ $-5.06 \mathrm{kcal} \mathrm{mole}{ }^{-1}$, obtained in this work. There is a very small change in entropy $(\Delta S=-0.70)$ in the reaction between methylene glycol and benzamide when the concentration of water is taken to be unity. If the values of the equilibrium constants in Table 8 are multiplied by the concentration of water, 
$55 \mathrm{~mole} / \mathrm{l}$, the entropy values are changed by $7.3 \mathrm{cal} / \mathrm{deg}$. mole. The addition of benzamide to formaldehyde is preferred to the addition of water owing to a decrease in enthalpy, which effect is partly cancelled by a simultaneous decrease in entropy.

Table 7. Activation parameters of the uncatalysed and catalysed reactions between formaldehyde and benzamide calculated using the total concentration of formaldehyde (I) and the concentration of unhydrated formaldehyde (II).

\begin{tabular}{llrrrrrr}
\hline$t^{\circ} \mathrm{C}$ & Catalyst & $\log A$ & $\begin{array}{c}\mathrm{I} \\
\mathrm{C} S^{*} \\
\mathrm{~mol} / \mathrm{deg} .\end{array}$ & $\begin{array}{c}\Delta H^{*} \\
\mathrm{kcal} / \mathrm{mole}\end{array}$ & $\log A$ & $\begin{array}{c}\mathrm{II} \\
\begin{array}{c}\Delta S^{*} \\
\mathrm{cal} / \mathrm{deg} . \\
\mathrm{mole}\end{array}\end{array}$ & $\begin{array}{c}\Delta H^{*} \\
\mathrm{kcal} / \mathrm{mole}\end{array}$ \\
\hline 75 & $\mathrm{H}^{+}$ & 10.75 & -11.58 & 19.35 & 8.23 & -23.15 & 11.35 \\
55 & $\mathrm{OH}^{-}$ & 12.38 & -4.08 & 15.10 & 9.85 & -15.65 & 7.10 \\
75 & $\mathrm{AcOH}$ & 8.25 & -23.08 & 18.70 & 5.72 & -34.65 & 10.70 \\
75 & $\mathrm{AcO}^{-}$ & 6.25 & -32.23 & 16.70 & 3.62 & -43.80 & 8.70
\end{tabular}

Table 8. Values of the equilibrium constant $K_{\mathrm{e}}=$ [methylolbenzamide]/[formaldehyde hydrate] [benzamide] in solutions in which $K_{\mathrm{e}}$ is independent of $\mathrm{pH}$. The enthalpies and entropy changes were calculated from values of $K_{\mathrm{e}}(\mathrm{I})$ and from values of $K_{\mathrm{e}}{ }^{\prime}=$ [methylol. benzamide]/[unhydrated formaldehyde][benzamide] (II), where $K=\left[\mathrm{CH}_{2}(\mathrm{OH})_{2}\right] /\left[\mathrm{CH}_{2} \mathrm{O}\right]$.

\begin{tabular}{cccccccccccc}
\hline$t^{\circ} \mathrm{C}$ & 0 & 25 & 40 & 60 & 75 & 90 & $\frac{\mathrm{kcal}}{\text { mole }}$ & $\frac{\Delta S}{\mathrm{cal}}$ & $\begin{array}{c}\Delta H \\
\text { deg.mole }\end{array}$ & $\frac{\mathrm{kcal}}{\text { mole }}$ & $\begin{array}{c}\Delta S \\
\text { cal }\end{array}$ \\
\hline$K_{\mathrm{e}, \mathrm{M}^{-1}}$ & 57 & 24.1 & 15.5 & 10.1 & 7.15 & 5.40 & -5.06 & -0.70 & -13.1 & -12.3
\end{tabular}

\section{REFERENCES}

1. Einhorn, A. Ann. 343 (1905) 207.

2. Einhorn, A. Ann. 361 (1908) 113.

3. Grove, Jr., G. A. and Lynch, C. C. J. Am. Chem. Soc. 72 (1957) 3622.

4. Koskikallio, J. Acta Chem. Scand. 10 (1956) 1267.

5. Uglestad, J. and de Jonge, J. Rec. Trav. Chim. 76 (1957) 919.

6. Ogata, Y., Kavasaki, A. and Okumura, N. Tetrahedron 22 (1966) 1731.

7. Glutz, A. and Zollinger, H. Angew. Chem. 77 (1965) 459.

8. Pfeil, E. and Schroth, G. Z. Anal. Chem. 34 (1952) 333.

9. Tommila, E. and Lindholm, M. Acta Chem. Scand. 5 (1951) 647.

10. Katritzky, A. J. and Waring, A. J. Tetrahedron 19 (1963) 465.

11. Iliceto, A. Gazz. Chim. Ital. 84 (1954) 536.

12. Bell, R. P. Advan. Phys. Org. Chem. 4 (1966) 7.

13. Martin, J. L. Australian J. Chem. 7 (1954) 400.

14. Bell, R. P. and Onwood, D. P. Trans. Faraday Soc. 58 (1962) 1557. 
15. Branch, G. E. K. and Clayton, J. O. J. Am. Chem. Soc. 50 (1928) 1685.

16. Robinson, R. A. and Stokes, R. H. Electrolyte Solutions, Butterworths, London 1959, pp. 229, 468, 514, 520.

17. Harned, H. S. and Owen, B. B. Physical Chemistry of Electrolytic Solutions, Reinhold, New York 1958, p. 645.

18. Jencks, W. P. Progr. Phys. Org. Chem. 2 (1964) 85.

Received September 27, 1969. 